\title{
Hygiene Analysis of Employee Food at Canteen the Axana Hotel Padang
}

\author{
Lise Asnur ${ }^{1}$, Sephira Dwika Aulia ${ }^{2}$ \\ \{lise.asnur@fpp.unp.ac.id\} \\ Tourism Department, Universitas Negeri Padang, Indonesia ${ }^{12}$
}

\begin{abstract}
This research originated from the researchers' observations of The Axana Padang Hotel, the problems that appear include: (1) Food or beverage equipment that looks dirty. (2) The place for storing foodstuffs is not neatly arranged, making it difficult to retrieve the ingredients to be used. (3) Uncovered food trash cans adjacent to processed or recently processed food. This study aims to determine the analysis of hygiene food which has indicators in the form of Cleanliness of Food and Beverage Equipment, Cleanliness of Food Storage, and Cleanliness in Food Processing at The Axana Hotel Canteen. This research is a descriptive study with qualitative data. Data were collected by interviewing, observation and documentation techniques, involving informants using techniques purposive sampling. The data were analyzed in a reduction manner, namely summarizing, selecting, focusing on important things, and analyzing the data obtained from the problem under study. Based on the results of the research that has been done, it shows that: (1) Unclean equipment and equipment before use are not washed first (2) The presence of cockroaches and insects in storage and storage areas for materials that are not neatly arranged (3) already processed not closed, food bins that are always open and the serving table is not clean.
\end{abstract}

Keywords: Hygiene Analysis; Employee Food; Axana Hotel; Padang

\section{Introduction}

"Tourism is a travel or vacation activity, while in general terms, tourism is a planned trip carried out individually, in groups from one place to another with the aim of obtaining a form of satisfaction and pleasure only" (Sinaga, 2010: 57). Padang City is the capital of West Sumatra, which is nicknamed the beloved city because of its natural beauty. Not only that, this city has many inns and tourists can enjoy its natural beauty and can enjoy food, one of which is Hotel the Axana Padang. Hotel The Axana Padang (previously known as Hotel Ambacang) is a star hotel (****), known as a city hotel because of its location in the middle of Padang and easy to visit. The hotel is located on Jalan Bundo Kanduang No.14-16 West Padang District, Padang City 25119, West Sumatra. And access is \pm 45 minutes from Minangkabau International Airport (BIM), \pm 25 minutes from Teluk Bayur Harbor, and \pm 15 minutes from Simpang Haru Train Station.

Departments are the parts that carry out specific tasks both within the organization and within the company. Hotel The Axana Padang has quite a number of employees, amounting to 89 people, so hotel operations can be run properly, with that employee at Hotel the Axana need manpower to run operations such as food and beverages. Given the importance of food for the body, of course, aspects must be considered hygiene. Hygiene Foods an effort to 
control food factors, people, places and their utensils that can or may cause illness or health problems (Yuliana, 2014: 5). The following indicators of hygiene food are [1] Cleanliness of Food and Beverage Equipment [2] Cleanliness of Food Storage [3] Cleanliness in Food Processing.

Based on preliminary observations on March 17, 2020, several problems were seen, including the dirty looking dispenser, dirty tables, unorganized food storage and uncovered food bins. Not just preliminary observations. An interview was also conducted with informants who had interned / PLI at The Axana Hotel, where the problems found in the canteen included cockroaches / insects in the food, unclean utensils, the floor where the dishwasher was always wet and always stepped on make the floor dirty and slippery. From these problems, The Axana Hotel needs to pay attention to cleanliness factors both from within and from outside, such as hygiene food. The Axana Hotel for employee food is still not hygiene, food hygiene is useful for employees to be healthy and free from disease and enthusiasm for work operations. Therefore, the researcher took the title concerning "Hygiene Analysis of Employee Food at Canteen the Axana Hotel Padang"

\section{Methodology}

This research is a descriptive study with qualitative data. Research location at The Axana Hotel Padang. The variable in this research is hygiene food. The informants of this research were the cook, the head of the canteen and the employees at The Axana Hotel, Padang, who used technique purposive sampling. Retrieval of data using interview techniques, observation and documentation. Data were analyzed using data reduction techniques, data presentation and drawing conclusions.

\section{Result and Discussion}

As for the results of interviews with several informants, it can be concluded that several things are:

\section{Cleanliness of food and beverage equipment}

At The Axana's canteen, the food and beverage utensils provided are clean because they are washed using warm water in the sink, and for the utensils they use stainless so they are not easily broken or cracked, and after washing the equipment is placed on a shelf that has been provided in the canteen.

\section{Cleanliness of food storage.}

Food or material storage is always cleaned and it is cleaned every day, and materials are separated from dry and wet materials, and food storage areas are neatly arranged, so that employees never have problems with the food they are given.

\section{Cleanliness in food Processing}

Cleanliness in food processing is maintained as seen from the cook who uses uniform a clean both from hats, gloves and masks, and when processing food, wash hands first and for 
food that has been processed closed so that dust does not enter and trash cans closed when processing food

Table 1. Research Observations on the Cleanliness of Food and Beverage Equipment

\begin{tabular}{ll} 
No. & \multicolumn{1}{c}{ Statement } \\
\hline 1. & Clean the equipment before use \\
2. & Tables and food containers are always cleaned \\
3. & Clean used food and beverage equipment \\
4. & Putting food and beverage utensils clean to avoid dust and dirt \\
5. & Availability of shelves for placing food utensils \\
6. & Sorting dirty equipment according to type \\
7. & Check for cracked or broken equipment \\
8. & Wear clean equipment \\
\hline
\end{tabular}

\section{Cleanliness of food and beverage equipment}

From the observations it can be concluded that the cleanliness of the equipment is not clean, it can be seen from the equipment before use, not cleaning, not cleaning tables and food containers, not placing food in clean places, and not using clean equipment.

\section{Cleanliness of food storage}

The results of the observation explained that, the storage of foodstuffs was not clean, due to the discovery of cockroaches in the chiller, not only that hair was also found in the foodstuff storage and for storing foodstuffs that were not neatly arranged so that it was difficult to remove.

\section{Cleanliness in food processing}

From the observations, it can be concluded that cleanliness in food processing is not clean. It can be seen from the slippery floors and dirty looks, trash cans that are always open, so they give off an unpleasant odor when processing food, materials to be processed or those that have been processed. processed not closed, the table where the food is served is not clean or looks dirty. The results of the specific findings, namely interviews that have been conducted with several informants, contradict the results of the interviews, where it can be concluded that the food served in the canteen is not hygiene. According to the Indonesian Ministry of Health in Yuliana (2014: 104) hygiene foodis an effort to control the factors of place, equipment, people and food that can or may cause health problems and food poisoning. Such as Food and Beverage Equipment Hygiene, Food Storage Hygiene, and Hygiene in Food Processing.

\section{Cleanliness of food and beverage equipment}

Based on the results of interviews, the food and beverage utensils provided in The Axana Padang Hotel canteen are clean because they are washed using warm water and soap from the sink, for the table it is always cleaned so that dirt does not stick, and for food utensils, be it 
dishes or the glass here uses stainless so it is not easily broken or cracked when dropped or used and after washing the equipment is placed on the shelf provided in the canteen. This is the same as the theory that has been put forward by Tumelap (in Riskawati 2017: 8) which states "Cleanliness of cutlery is a very important part and affects the quality of food and beverages. Cutlery that is not washed properly can cause germs that are left behind to multiply and contaminate the food that will be placed on it".

Meanwhile, based on observations that have been made, contrary to the results of interviews with informants, where there are several problems including, the equipment used looks dirty, such as a dispenser, and for the place to cook the rice it looks very dirty, because the tools used to process rice are not cleaned or not. washed first, do not clean the table and food containers, do not place food in a clean place, and do not use clean utensils.

Based on the results of the above research, it shows that food and beverage equipment does not meet hygiene requirements, seen from the results of observations, such as cleanliness of beverage equipment, namely dirty yellow dispensers and equipment before use is not cleaned or not washed first.

\section{Cleanliness of food storage}

Based on the results of interviews, food storage is always cleaned and it is cleaned every day, and materials are separated from dry and wet materials, and food storage places are neatly arranged so as not to have trouble picking up the materials to be used, that way employees have never encountered a problem with the available food. This is the same as the theory put forward by the Ministry of Health (in Mahadi 2017: 5) which states, "Food storage is a procedure for organizing, storing, maintaining the safety of dry and wet food ingredients both in quality and quantity in the warehouse of dry and wet foodstuffs and recording. and reporting, the principle of storing foodstuffs must be in accordance with the temperature."

Meanwhile, based on observations that have been made, contrary to the results of interviews with informants where there are several problems including, food storage is not clean, because there are cockroaches visible, not only cockroaches, plastic containers Empty foodstuffs are still visible in the chiller and foodstuffs are not neatly arranged.

Based on the above results, showed no clean food storage, because it does not meet the requirements of cleanliness or hygiene, where the presence of cockroaches in place of storage, as well as for storage not well organized so as to take the materials to be used are difficult to reach by hand.

\section{Cleanliness in food processing}

Based on the results of interviews, cleanliness in food processing is maintained as seen from the cook who uses uniform a clean, both from hats, gloves and masks, and when processing food, wash hands first and for food that has been processed closed so that dust do not enter and closed bins when processing food. This is the same as the theory put forward by the Indonesian Ministry of Health, 2004, that food processing is a process of changing the form from raw materials to ready-to-eat food, good food processing is that which follows principles hygiene, in this case the requirements for food processing personnel, equipment and conditions of the place up to processing food are always considered.

Meanwhile, based on observations made, contrary to the results of interviews with informants, where there were several problems including, the floor was not clean due to water dripping from the washing area which made the streets slippery, food bins that were always open when processing food, food or other ingredients. will be processed not closed, the table where the food is served is not clean. 
Based on the results of the above research, it shows that cleanliness in food processing does not meet the hygiene requirements, where seen from his observations, food bins are always open when processing food, so that it will emit an unpleasant smell, does not close the food to be processed or the food has been processed, and the table for serving food looks dirty.

\section{Conclusion}

The cleanliness of the food and beverage equipment in The Axana Padang Hotel canteen does not meet the requirements hygiene, where the equipment is not clean, for example the dispenser is dirty and yellow, and the equipment before use is not cleaned or washed first. The cleanliness of the storage of foodstuffs at The Axana Padang Hotel canteen does not meet the requirements of hygiene or hygiene, where there are cockroaches in the storage area, and for storage it is not neatly arranged so that it is difficult to reach the materials to be used by hand. Cleanliness in the food processing of The Axana Padang Hotel canteen does not meet the hygiene and health requirements, it can be seen that the food trash can is always open when processing food, so it will emit an unpleasant odor, does not close the food to be processed or the food has been processed, and the table for serving food looks dirty.

\section{References}

[1] Dr.Yuliana ,SP,M.SI.2014.Hygiene Dan Sanitasi Hotel.Padang:Program Studi Manajemen Perhotelan Jurusan Kesejahteraan Keluarga Fakultas Teknik Unversitas Negeri Padang

[2] Muhadi,Ihsan.2017. Implementasi Penyimpanan Bahan Makanan Di Fakultas Pariwisata Dan Perhotelan Universitas Negeri Padang : Journal (diakses tanggal 5 September 2020)

[3] Riskawati.2017.Gambaran Higiene dan Sanitasi Terhadap Bakteri Pada Alat Makan Di Kantin Sekolah Dasar Pulau Barran Lompo Kecamatan Kepulauan Sangkarrang : Skripsi (diakses tanggal 5 September 2020)

[4] Sinaga.2010.Potensi dan Pengembangan Objek Wisata di Kabupaten Tapanuli Tengah .Kertas Karya.Program DIII Pariwisata .Universitas Sumatera Utara 